\title{
Physical Examination Findings Among Children and Adolescents With Obesity: An Evidence-Based Review
}

Sarah Armstrong, MD, ${ }^{a}$ Suzanne Lazorick, MD, MPH, ${ }^{b}$ Sarah Hampl, MD, ${ }^{c}$ Joseph A. Skelton, MD, MS, ${ }^{d}$ Charles Wood, MD, MPH, ${ }^{e}$ David Collier, MD, PhD, ${ }^{b}$ Eliana M. Perrin, MD, MPHe

Overweight and obesity affects 1 in 3 US children and adolescents. Clinical recommendations have largely focused on screening guidelines and counseling strategies. However, the physical examination of the child or adolescent with obesity can provide the clinician with additional information to guide management decisions. This expert-based review focuses on physical examination findings specific to children and adolescents with obesity. For each physical examination element, the authors define the finding and its prevalence among pediatric patients with obesity, discuss the importance and relevance of the finding, describe known techniques to assess severity, and review evidence regarding the need for additional evaluation. The recommendations presented represent a comprehensive review of current evidence as well as expert opinion. The goal of this review is to highlight the importance of conducting a targeted physical examination during pediatric weight management visits.

\section{BACKGROUND}

Despite recent declines in the prevalence of obesity in certain populations, the overall number of children and adolescents affected by obesity is $17 \%$, or 12.7 million nationally. The clinical care of children and adolescents with obesity is challenging. Current clinical recommendations encourage clinicians to discuss weight status in a sensitive, nonjudgmental manner, assess lifestyle habits, provide patientcentered counseling to facilitate change, and identify chronic health conditions; the physical examination has received limited attention.

A comprehensive understanding of physical examination findings associated with obesity can aid the clinician in several ways. First, many findings can be quantified, helping the clinician triage further evaluation and management. Second, explaining physical findings may raise parent awareness of the consequences of obesity. Finally, longitudinal tracking of findings can help the clinician monitor response to treatment.

\section{METHODS}

The authors include clinical and research faculty specializing in childhood obesity. Authors identified and prioritized the key physical examination findings collectively, then performed a literature search from 1975 to present using 2 databases (PubMed and Cochrane) and structured MESH search terms ("condition"[tiab] AND "obesity" AND ["clinical exam" OR "exam findings] limited to studies published in English, and age 0 to 18 years. The strength of the evidence was low. Most published data are observational and thus associative rather than predictive. a Duke University Medical Center, Durham, North Carolina ${ }^{b}$ East Carolina University, Greenville, North Carolina; ${ }^{c}$ Children's Mercy Hospital and Center for Children's Healthy Lifestyles and Nutrition, Kansas City, Missouri; ${ }^{d}$ Wake Forest School of Medicine, Winston-Salem, North

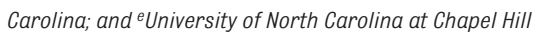
School of Medicine, Chapel Hill, North Carolina

Drs Armstrong conceptualized the review, designed the review criteria and section headings, conducted the literature search and literature review, drafted portions of the manuscript, revised the manuscript, reviewed references for accuracy, and contributed critical review of content and structure; Dr Skelton conceptualized the review, conducted the literature search and literature review, drafted portions of the manuscript, and revised the manuscript; $\mathrm{Dr}$ Perrin conceptualized the review, conducted the literature search and literature review, drafted portions of the manuscript, revised the manuscript, and contributed resources for administrative help;

To cite: Armstrong S, Lazorick S, Hampl S, et al. Physical Examination Findings Among Children and Adolescents With Obesity: An Evidence-Based Review. Pediatrics. 2016;137 (2):e20151766 
The resultant expert-based review summary does not aim to provide screening recommendations but rather to alert the clinician to the presence of physical findings and to provide a framework for managing identified conditions. The authors have purposefully chosen physical examination findings that are most prevalent and are most likely to affect clinical decision-making. A summary is provided in Table 1 .

\section{VITAL SIGNS}

\section{Hypertension}

Normal systolic (SBP) and diastolic (DBP) blood pressure is defined as $<95$ th percentile for the child's age, gender, and height percentile. ${ }^{1}$ Stage 1 hypertension (HTN) is SBP and/or DBP $\geq 95$ th percentile but $<99$ th percentile+5 $\mathrm{mm} \mathrm{Hg}$; Stage $2 \mathrm{HTN}$ is SBP and/or DBP >99th percentile $+5 \mathrm{~mm} \mathrm{Hg}$. It is important to measure BP by auscultation with a cuff that covers $\geq 80 \%$ of the midarm circumference; a smaller cuff can result in artificially high readings. ${ }^{1}$ Ambulatory $\mathrm{BP}$ monitoring demonstrates that daytime SBP, DBP, and mean arterial BP increase significantly with increasing BMI. 25 Although the pathophysiology of HTN in children with obesity is not fully understood, ${ }^{26}$ hyperinsulinemia, adipokine activation, perinephric fat effects on the kidney and cytokine action on the vascular endothelium, and cortisol and nitric oxide levels are contributory. ${ }^{27-29}$

Diagnosing and managing HTN quickly and effectively may affect long-term morbidity. Increased BMI in childhood predicts arterial stiffening in adulthood, and that effect is mediated by the presence or absence of HTN. ${ }^{30}$ Early management may prevent renal complications; albuminuria ${ }^{31}$ and end-stage renal disease $^{32}$ are more common in patients with obesity and HTN compared with obesity alone.
The evaluation of a child with obesity and HTN (confirmed by averaging three readings during the same encounter) should include a urinalysis, blood creatinine, and a renal and cardiac ultrasound. ${ }^{33}$ Almost half of children with high BP demonstrate left ventricular hypertrophy (LVH) by echocardiogram; children with higher BMI $z$ scores are 3 times more likely to demonstrate LVH than healthy-weight peers. ${ }^{34,35}$ The presence of LVH indicates more severe or long-standing disease and should prompt the clinician to manage BP aggressively. ${ }^{33}$ Weight loss is the primary recommended treatment of youth with obesity and HTN and may be aided by the use of a Cardiovascular Health Integrated Lifestyle Diet (CHILD-1) diet. $^{33}$ Pharmacologic treatment is recommended for children with stage 2 HTN, LVH, or stage 1 HTN persisting for $>6$ months. ${ }^{33}$

\section{Elevated Resting Heart Rate}

Tachycardia is commonly defined as a heart rate (HR) $>140$ beats / minute for children and $>100$ beats/minute for adolescents. ${ }^{36}$ Resting HR increases with higher $\mathrm{BMI}^{37,38}$ because of impaired autonomic nervous system function with increased sympathetic tone and decreased $\beta$-adrenergic responsiveness. ${ }^{38,39}$ Routine HR surveillance is recommended because tachycardia may predict later development of HTN in children. ${ }^{15}$ Although the long-term complications of high resting HR among children are unknown, tachycardia among adults is a strong predictor of excessive cardiovascular mortality and is associated with other risk factors, including HTN, elevated blood glucose, hyperinsulinemia, and lipid abnormalities. ${ }^{40}$

\section{Changes in Height Velocity}

Between ages 2 to 8, each 1 unit of $\mathrm{BMI}$ increase is related to a modest increase in height $(+0.23 \mathrm{~cm}$ in boys and $+0.29 \mathrm{~cm}$ in girls). In addition, children who develop obesity early in life demonstrate an earlier onset of peak height velocity, 1.5 months earlier per BMI unit increase. ${ }^{41} \mathrm{At}$ this time of peak height velocity, precocious puberty may emerge, leading to significant slowing of height growth between ages 8 and 18. Overall, this results in net shorter adult height for children who develop obesity before the onset of puberty (4.79 and $3.08 \mathrm{~cm}$ for boys and girls, respectively). ${ }^{41}$ The clinician should carefully monitor height velocity and correlate with pubertal staging.

\section{HEAD, EYE, EAR, NOSE, AND THROAT EXAMINATION}

\section{Papilledema}

An uncommon but concerning complication of obesity is pseudotumor cerebri, or idiopathic intracranial hypertension (IIH). Among adolescents, IIH presents most commonly in an adolescent female with obesity who complains of morning headache, headache with Valsalva, and nausea and vomiting. On examination, the patient may demonstrate blurred/ decreased vision or diplopia, facial nerve palsies, pulsatile tinnitus, ataxia, dizziness, and upper back musculoskeletal pain. ${ }^{42}$ Although papilledema is present in only $50 \%$ of patients with IIH and elevated intracranial pressure, ${ }^{43}$ it may be the only presenting sign/ symptom of IIH in children. ${ }^{44}$ Papilledema refers to swelling of the optic disc secondary to increased intracranial pressure. The Frisen Scale is used to score the severity of papilledema (Fig 1). A patient with an abnormal funduscopic examination should be referred urgently to an ophthalmologist. A lumbar puncture can be safely performed on a conscious patient with no focal neurologic findings and normal brain 
TABLE 1 Summary of Recommendations

\begin{tabular}{|c|c|c|c|}
\hline & $\begin{array}{l}\text { Physical } \\
\text { Examination } \\
\text { Finding }\end{array}$ & Definition & Other Causes/Differential \\
\hline \multirow[t]{2}{*}{ Vital signs } & Hypertension & $\begin{array}{l}\text { SBP or } \mathrm{DBP} \geq 95 \text { th percentile on at } \\
\text { least } 3 \text { readings }{ }^{1}\end{array}$ & $\begin{array}{l}\text { Numerous, including essential, stress-induced, renal parenchymal or vascular } \\
\text { disease, cardiovascular disorders, obstructive sleep apnea syndrome, } \\
\text { substance abuse or medication side effect, pheochromocytoma, anemia, } \\
\text { hyperthyroidism, Cushing syndrome, Williams syndrome, Turner syndrome }\end{array}$ \\
\hline & Increased HR & & $\begin{array}{l}\text { Numerous, including fever, anemia, drugs, anxiety, pain, arrhythmia, } \\
\text { myocarditis, substrate deficiency, hypovolemic shock, sepsis, anaphylaxis, } \\
\text { toxic exposure, hyperthyroidism, Kawasaki disease, acute rheumatic fever, } \\
\text { pheochromocytoma }\end{array}$ \\
\hline \multirow[t]{3}{*}{ Anthropometric } & $\begin{array}{l}\text { Changes in height } \\
\text { velocity }\end{array}$ & Early height velocity increase & $\begin{array}{l}\text { True pattern characteristic of obesity, but early height increases can also be: } \\
\text { familial tall stature, precocious puberty, gigantism, pituitary gland tumor }\end{array}$ \\
\hline & & $\begin{array}{l}\text { Earlier onset of peak height } \\
\text { velocity }\end{array}$ & $\begin{array}{l}\text { Slowing of height can be due to medications, inflammatory bowel disease, } \\
\text { hypothyroidism, hypercortisolism, dysplastic or genetic syndrome, } \\
\text { constitutional delay, growth hormone deficiency }{ }^{4}\end{array}$ \\
\hline & & Slowing of height age 8-18 y & \\
\hline \multirow[t]{3}{*}{ HEENT } & Papilledema & $\begin{array}{l}\text { Swelling of the optic disc } \\
\text { secondary to increased } \\
\text { intracranial pressure (Frisen } \\
\text { scale) }\end{array}$ & $\begin{array}{l}\text { Intracranial mass lesion, hydrocephalus, cerebral venous thrombosis, } \\
\text { medications, autoimmune disorders, anemia, and cranial venous outflow } \\
\text { abnormalities }^{5}\end{array}$ \\
\hline & Dental caries & $\begin{array}{l}\text { White, brown, or black spots } \\
\text { (noncavitary) or eroded areas } \\
\text { of enamel or dentin (cavitary) }\end{array}$ & Developmental disease of the tooth and gum, trauma, infection \\
\hline & $\begin{array}{l}\text { Tonsillar } \\
\text { hypertrophy }\end{array}$ & $\begin{array}{l}\text { Tonsils occupy at least } 50 \% \text { of } \\
\text { the oropharynx (Brodsky } \\
\text { classification } 3+\text { and } 4+\text { ) }\end{array}$ & Infectious causes, lodged foreign body \\
\hline \multirow[t]{2}{*}{ Chest } & Gynecomastia & $\begin{array}{l}>2 \mathrm{~cm} \text { of breast tissue in boys or } \\
\text { men }^{6}\end{array}$ & $\begin{array}{l}\text { Hyperaromatase syndrome }{ }^{7} \text {; hypogonadism, hyperprolactinemia, chronic liver } \\
\text { disease, and medications, particularly } \mathrm{H} 2 \text { antagonists }^{8}\end{array}$ \\
\hline & $\begin{array}{l}\text { Cervicodorsal } \\
\text { hump }\end{array}$ & $\begin{array}{l}\text { Fibrous fatty tissue over the upper } \\
\text { back and lower neck }\end{array}$ & $\begin{array}{l}\text { Endogenous (Cushing syndrome) or exogenous corticosteroid exposure, } \\
\text { adrenal carcinoma, adrenal adenoma; HIV with secondary hyperinsulinemia }{ }^{9}\end{array}$ \\
\hline Gastrointestinal & $\begin{array}{r}\text { Liver enlargement } \\
\text { (hepatomegaly) }\end{array}$ & $\begin{array}{l}\text { Liver span }>5 \mathrm{~cm} \text { in } 5 \text {-y-olds and } \\
15 \mathrm{~cm} \text { in adults or liver edge } \\
\text { palpable below the right costal } \\
\text { margin by }>3.5 \mathrm{~cm} \text { in adults or } \\
>2 \mathrm{~cm} \text { in children }{ }^{10,11}\end{array}$ & $\begin{array}{l}\text { Multiple, including hepatitis, storage disorders, infiltrative, impaired outflow, } \\
\text { and biliary tract disorders }\end{array}$ \\
\hline Genitourinary & Buried penis & $\begin{array}{l}\text { Suprapubic fat accumulation } \\
\text { leading to the appearance of a } \\
\text { shortened penile shaft }\end{array}$ & Trapped penis, webbed penis, and micropenis ${ }^{12}$ \\
\hline \multirow[t]{7}{*}{ Musculoskeletal } & Gait & $\begin{array}{l}\text { Collapse into hip ("waddle") or } \\
\text { Trendelenberg-like gait }\end{array}$ & Arthritis, Blount disease, SCFE \\
\hline & Scoliosis & $\begin{array}{l}\text { Lateral curvature of the spine }>10 \\
\text { degrees on examination, } 20 \\
\text { degrees on radiography }\end{array}$ & $\begin{array}{l}\text { Infantile idiopathic scoliosis, juvenile idiopathic scoliosis, congenital vertebral } \\
\text { anomaly, syndromic spinal deformity }{ }^{13}\end{array}$ \\
\hline & Lordosis & $\begin{array}{l}\text { Trunk sway associated with } \\
\text { postural adaptations }\end{array}$ & Spondylolisthesis, achondroplasia, muscular dystrophy, other genetic conditions \\
\hline & SCFE & $\begin{array}{l}\text { Knee or hip pain, subacute onset, } \\
\text { pain with external rotation } \\
\text { of hip }\end{array}$ & $\begin{array}{l}\text { Multiple problems present with chronic hip, knee, or thigh pain including } \\
\text { growing pains, femoral neck fracture, groin injury, Perthes disease, } \\
\text { osteonecrosis associated with systemic disease, juvenile idiopathic arthritis, } \\
\text { reactive arthritis, overuse injuries, chondrolysis, tumors, osteitis pubis }{ }^{14}\end{array}$ \\
\hline & $\begin{array}{l}\text { Genu varum/ } \\
\text { valgum }\end{array}$ & Genu varum (bow legs) & Tibia vara (Blount disease), rickets, skeletal dysplasia, celiac sprue ${ }^{15}$ \\
\hline & & Genu valgum (knock-kneed) & $\begin{array}{l}\text { Physiologic in children under } 6 \text { y; in older children and adolescents, consider } \\
\text { postaxial limb deficiency, neoplasms, genetic and metabolic disorders, } \\
\text { neurofibromatosis, and vitamin D-resistent rickets }{ }^{15}\end{array}$ \\
\hline & Pes planus & $\begin{array}{l}\text { Rigid vs flexible, sometimes with } \\
\text { pain }\end{array}$ & $\begin{array}{l}\text { Posterior tibial tendon insufficiency, tarsal coalition, congenital vertical talus, } \\
\text { rheumatoid arthritides, trauma, neuropathy }{ }^{16}\end{array}$ \\
\hline Skin & Acanthosis & $\begin{array}{l}\text { AN is thickened and darker skin, } \\
\text { occasionally pruritic, at nape of } \\
\text { the neck (99\%), axillae ( } 73 \%) \text {, } \\
\text { and less commonly, groin, } \\
\text { eyelids, dorsal hands, and other } \\
\text { areas exposed to friction } 17,18\end{array}$ & Medication side effect, ${ }^{18}$ and uncommonly, visceral malignancy. ${ }^{19}$ \\
\hline
\end{tabular}




\begin{tabular}{|c|c|c|}
\hline $\begin{array}{l}\text { Physical } \\
\text { Examination } \\
\text { Finding }\end{array}$ & Definition & Other Causes/Differential \\
\hline \multirow{3}{*}{ Hirsutism/acne } & Burke scale to quantify20 & \\
\hline & $\begin{array}{l}\text { PCOS is based on Rotterdam } \\
\text { Consensus, requiring } 2 \\
\text { of: clinical evidence of } \\
\text { hyperandrogenism (acne, } \\
\text { hirsutism, male-pattern } \\
\text { alopecia), ovulatory dysfunction } \\
\text { (chronic anovulation/irregular } \\
\text { menses), and polycystic } \\
\text { ovaries }^{21}\end{array}$ & Hirsutism: familial, Cushing syndrome, thyroid disorders \\
\hline & & Acne: physiologic, folliculitis, rosacea \\
\hline Striae & $\begin{array}{l}\text { Linear, usually symmetrical } \\
\text { smooth bands of atrophic } \\
\text { skin that initially appear } \\
\text { erythematous, progressing } \\
\text { to purple then white; } \\
\text { perpendicular to the direction } \\
\text { of greatest tension in areas } \\
\text { with adipose tissue }{ }^{22}\end{array}$ & Pregnancy, Cushing syndrome, and topical corticosteroid use \\
\hline Intertrigo & $\begin{array}{l}\text { Macerated, erythematous plaques } \\
\text { in skin folds }{ }^{23}\end{array}$ & $\begin{array}{l}\text { Inflammatory diseases, metabolic disorders, malignancies (rare in pediatrics), } \\
\text { and various infections by site }\end{array}$ \\
\hline Pannus & $\begin{array}{l}\text { Excess skin and subcutaneous fat } \\
\text { below the umbilicus. }{ }^{24}\end{array}$ & Pregnancy, malignancy \\
\hline
\end{tabular}

HEENT, head, eye, ear, nose, and throat examination.

imaging, even in the presence of papilledema. ${ }^{45}$

\section{Dental Caries}

Obesity and dental caries are strongly correlated, ${ }^{47,48}$ especially for permanent dentition. ${ }^{48}$ This relationship is stronger with increasing age and lower socioeconomic status. ${ }^{48}$ Children with obesity have decreased salivary flow rate, ${ }^{49}$ lower concentrations of salivary phosphate, lower salivary peroxidase activity and higher concentrations of free sialic acid and proteins, all of which predispose to caries. ${ }^{50}$ Children with Prader-Willi syndrome are at highest risk. ${ }^{51,52}$ In addition, children with obesity have more erupted teeth ${ }^{53,54}$ and their teeth erupt earlier ${ }^{53}$ than children with healthy weight. Altered timing of tooth eruption can lead to malpositioned teeth and/or tooth crowding, which makes good oral hygiene difficult to maintain. ${ }^{53}$ The dental examination should include careful inspection of all tooth surfaces for white, brown, or black discolorations (noncavitated caries) and for erosions in the enamel or dentin (cavitated caries). Counseling to promote good oral hygiene should include limitations on sticky foods, sugary beverages and diet beverages containing citric acid. Children with caries should be referred for dental evaluation and treatment.

\section{Wide Neck and Adenotonsillar Hypertrophy}

In adults, large neck circumference (as measured just above the cricothyroid cartilage) is associated with cardiometabolic risk and obstructive sleep apnea (OSA). .5-57 $^{\text {5 }}$ Among children, neck circumference is correlated with blood pressure, lipids, and insulin, ${ }^{58}$ but not OSA. ${ }^{59}$ Neck circumference measurement is of limited clinical value and not routinely recommended.

The presence of tonsillar hypertrophy does not increase the likelihood that a child with obesity has OSA but does predict severity. ${ }^{60,61}$ Obese children with tonsillar hypertrophy are more likely to have noisy breathing, restless sleep, behavior difficulties, snoring, and daytime sleepiness. ${ }^{62}$ Tonsillar hypertrophy is considered significant when tonsils occupy at least $50 \%$ of the oropharynx (Brodsky classification 3+ and 4+, Table 2). The physical examination of the child with obesity should routinely include a quantification of tonsillar size. A Brodsky score of $\geq 3$ should prompt evaluation for signs and symptoms consistent with OSA and, if positive, referral for overnight polysomnography.

\section{CHEST AND BACK}

\section{Gynecomastia}

Gynecomastia, defined as $>2 \mathrm{~cm}$ of breast tissue in boys or men, ${ }^{6}$ is found in up to $40 \%$ of adolescent boys with obesity due to peripheral conversion of testosterone to estradiol in adipocytes. ${ }^{8}$ Gynecomastia is not limited to boys with obesity but increases with increasing body weight. ${ }^{6}$ Gynecomastia is typically bilateral 
TABLE 2 Brodsky Classification of Tonsil Size

\begin{tabular}{ll}
\hline Grade & Finding \\
\hline 0 & Tonsils in fossa or removed \\
$1+$ & $<25 \%$ oropharynx occupied \\
$2+$ & $25 \%-50 \%$ oropharynx occupied \\
$3+$ & $50 \%-75 \%$ oropharynx occupied \\
$4+$ & $>75 \%$ oropharynx occupied \\
\hline
\end{tabular}

(but can be unilateral), is correlated with increasing amount of body hair, and is associated with early sexual maturation. ${ }^{6}$

Gynecomastia is uncommon in prepubertal boys and when present should be evaluated to rule out underlying pathology such as hyperaromatase syndrome. ${ }^{7}$ Less common causes of gynecomastia include hypogonadism, hyperprolactinemia, chronic liver disease, and medications, particularly $\mathrm{H} 2$ antagonists. ${ }^{8}$ Breast cancer is rare among male children and adolescents. Klinefelter syndrome 47 , XXY is the most common genetic cause of gynecomastia. ${ }^{63}$

Most cases of gynecomastia can be managed with reassurance and may improve with BMI reduction. However, gynecomastia that persists past age 18 or is associated with significant obesity is less likely to resolve. Surgical correction is an available treatment option for cases that do not resolve by adulthood or for reasons of psychosocial stress. ${ }^{64}$ Although patients with obesity typically require more extensive reconstruction, there is no difference in complications or patient satisfaction postoperatively compared with healthy-weight patients; thus, obesity should not be considered a contraindication to surgery. ${ }^{65}$

\section{Cervicodorsal Hump}

Cervicodorsal hump ("buffalo hump") is a well-defined clinical finding in patients with excess endogenous (Cushing syndrome) or
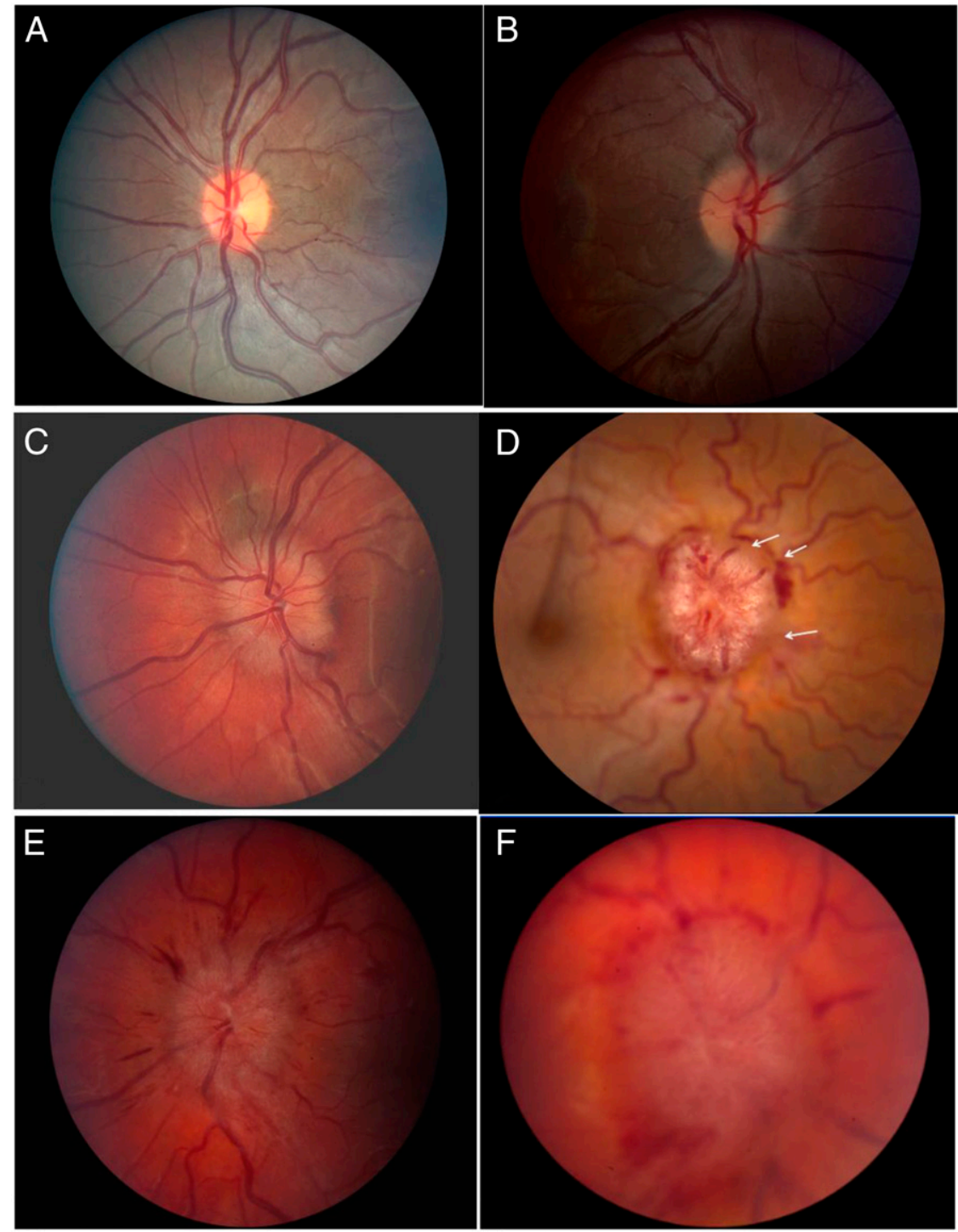

FIGURE 1

Frisen Graded Scale of papilledema. Fundus photographs representative of each Modified Frisén Scale grade ${ }^{46,155}$ A, Grade 0: normal optic disc. B, Grade 1: C-shaped halo with a temporal gap. C) Grade 2: circumferential halo. D, Grade 3: obscuration of multiple major vessels as they exit the optic disc (arrows). E, Grade 4: obscuration of major vessels on the optic disc. F, Grade 5: complete obscuration of one major vessel and at least partial obscuration of the rest. (Photographs and descriptions kindly provided by Michael Wall, MD, Department of Ophthalmology and Visual Sciences, Carver School of Medicine, University of lowa. $)^{46}$

exogenous corticosteroid exposure, and secondary hyperinsulinemia. ${ }^{9}$ It appears as a soft mound of tissue at the posterior nape of the neck. Although it can be a physical nuisance, it is generally a benign clinical finding. This localized adiposity is found in the majority of adults with obesity, regardless of comorbid conditions. Cervicodorsal hump occurs in children with obesity with no laboratory abnormalities. ${ }^{66}$
This finding, in the absence of other clinical signs of steroid excess, should not prompt the clinician to conduct further investigation.

\section{GASTROINTESTINAL}

\section{Right Upper Quadrant Pain and Hepatomegaly}

Right upper quadrant pain and/ or hepatomegaly may help identify 
children with nonalcoholic fatty liver disease (NAFLD). NAFLD is a spectrum of disease from fatty infiltration, inflammation, nonalcoholic steatohepatitis, cirrhosis, and end-stage liver failure. NAFLD is present in $13 \%$ of the general pediatric population ${ }^{67}$ but in $>50 \%$ of adolescents who are overweight or obese. It is more common among boys and those of Hispanic ethnicity. ${ }^{68}$

No physical examination finding is diagnostic for NAFLD; liver biopsy is the gold standard. However, among children with biopsy-diagnosed NAFLD, abdominal pain is the most common symptom (46\%), followed by hepatomegaly (27\%). ${ }^{69}$ Right upper quadrant pain consistent with biliary colic should suggest cholelithiasis, also associated with obesity. ${ }^{70}$

Hepatomegaly is defined as a liver span greater than age norms $(5 \mathrm{~cm}$ in 5 -year-olds and $15 \mathrm{~cm}$ in adults) or liver edge palpable below the right costal margin by $>3.5 \mathrm{~cm}$ in adults or $>2 \mathrm{~cm}$ in children..$^{10}$ The difficulty of detecting hepatomegaly in patients with obesity, even by trained hepatologists, limits the identification of children with NAFLD. ${ }^{71,72}$ The "scratch" test may help identify the liver edge when palpation is difficult due to body habitus (Fig 2) but does not correlate well with liver span as measured by ultrasound, and discrepancies increase with increasing BMI. ${ }^{73}$

Any symptoms of abdominal pain or the finding of hepatomegaly should prompt an evaluation, including measurement of transaminases and consideration of liver ultrasound or referral to a pediatric hepatologist where available. ${ }^{74}$

\section{GENITOURINARY}

\section{Inconspicuous Penis}

Inconspicuous penis ("buried penis" or "hidden penis") is the
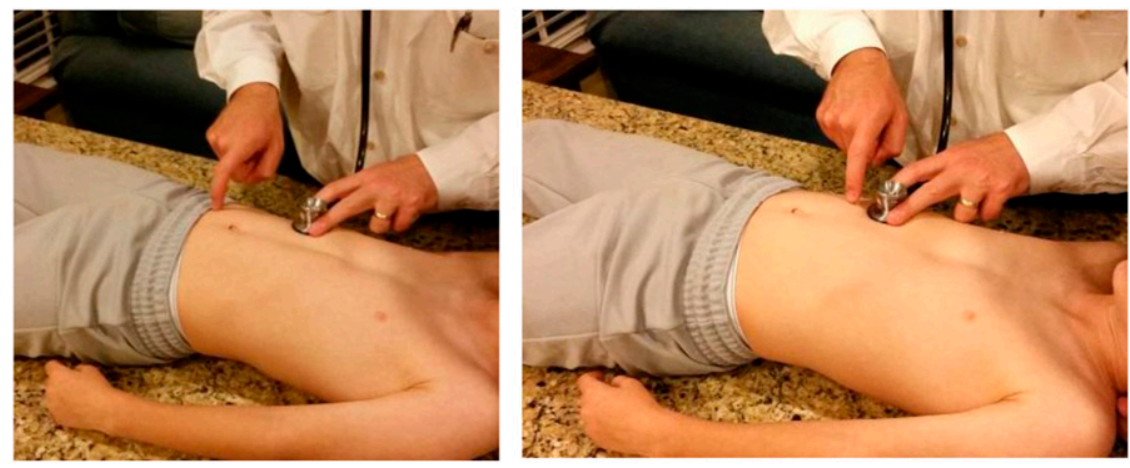

FIGURE 2

Scratch test for hepatomegaly. Photographs courtesy of Joseph Skelton (coauthor).

result of an enlarged suprapubic fat pad that conceals a normally developed, normally sized penis. This should be distinguished from webbed penis (scrotal skin extends ventrally along penile shaft) and trapped penis (shaft is bound in scar tissue), which require surgical evaluation. Micropenis is penile length is $<2.5 \mathrm{SD}$; this is likely related to underlying endocrine abnormalities and appears in infancy or early childhood. Inconspicuous penis presents in early childhood, as the suprapubic fat accumulates and leads to the appearance of a shortened penile shaft. Although there is no underlying penile abnormality, the fat pad may obstruct the urinary outlet, causing recurrent urinary tract infections, balanitis, and eventually penile adhesions. ${ }^{75}$ Treatment should focus on hygiene and regular voiding. For patients with significant complications or quality-of-life impairment as a result of inconspicuous penis, surgical options may be considered. ${ }^{12,75-77}$

\section{MUSCULOSKELETAL}

\section{Gait}

It is widely believed that children with obesity adapt their gait to accommodate increased mass. ${ }^{78,79}$ Kinematic studies show that, while walking, children with obesity collapse into hip adduction on the weight-bearing side ("waddle" or Trendelenburg-like gait) and apply more genu valgum stresses. This gait increases the risk for knee pain and osteoarthritis. ${ }^{80}$ Gait evaluation is a clinical tool to assess for the musculoskeletal conditions described later, and physical therapy evaluation should be considered when pain or abnormalities are present.

\section{Scoliosis}

Children with obesity have a similar prevalence of scoliosis to their healthy-weight peers..$^{79,81}$ Scoliosis is a lateral curvature of the spine > 10 degrees; most cases are idiopathic. ${ }^{82}$ Clinical examination includes evaluation of symmetry of shoulders and hips, and the Adam's forward bending test. Posterioranterior and lateral radiography provides measurement of Cobb angles. A Cobb angle $>20$ degrees is considered abnormal. Among adolescents, higher BMIs are protective against the development of scoliosis; however, the cases that do occur tend to be more severe with greater curvature of the spine, ${ }^{81}$ curve progression, less successful results with bracing (orthotics), ${ }^{83}$ and increased perioperative complications. ${ }^{84}$ Scoliosis may be more difficult to assess accurately in children with obesity; the clinician should quantify the degree of curvature with imaging and consider early 
referral for orthotic management as indicated. Of note, as long as pain is not a factor, scoliosis should not limit physical activity, ${ }^{85}$

\section{Lordosis}

Postural adaptations that occur in the developing spine in response to high body weight are also associated with low back pain. Lordosis, or excessive inward curvature of the spine, is common among adolescents with high BMI and a cause of low back pain. In photos of sagittal spine posture, adolescents with obesity have greater hyperlordotic posture and "trunk-sway."79,86 Physical therapy may improve posture to delay or avoid chronic low-back pain.

\section{Slipped Capital Femoral Epiphysis}

Slipped capital femoral epiphysis (SCFE) is a condition in which the proximal femoral metaphysis separates from the epiphysis of the femoral head. ${ }^{87}$ SCFE is the most common hip disorder of adolescence with a prevalence of 10.8 cases per 100000 children. It is most common during early adolescence when children are growing rapidly. ${ }^{88,89}$ Although the exact cause is unknown, several risk factors have been identified, including obesity, femoral retroversion, and hormonal disorders (hormone deficiency, hypothyroidism, low testosterone). ${ }^{90}$ Patients with SCFE present with chronic knee, hip, or thigh pain, or a limp. Rarely, it is noted after an acute traumatic episode. ${ }^{87}$ SCFE is strongly correlated with high BMI, male gender, and early adolescence. The average age at occurrence (12-14 years) decreases with increasing obesity. ${ }^{79,91}$ Children with high BMIs are more likely to have bilateral SCFE. In a study of children with SCFE, $20 \%$ of children had bilateral disease, and every child with a BMI >35 eventually progressed to bilateral disease. ${ }^{92}$ SCFE is among the most commonly missed diagnoses in children, with an average delay in diagnosis of 6 months. ${ }^{90}$ Complications of a progressing slip include avascular necrosis, chondrolysis, and osteoarthritis; early diagnosis and treatment is critical. ${ }^{88,93}$ Diagnosis is suggested by acute or subacute onset of hip or knee pain in a child with obesity. The examination reveals pain with external rotation of the hip, and diagnosis is confirmed by bilateral hip radiography, which should include anteroposterior and frog-leg or cross-table lateral views. The patient should be made non-weight bearing to prevent progression to a more severe slip and referred for urgent orthopedic evaluation. ${ }^{94}$ Treatment of SCFE is in situ placement of a cannulated screw across the physis under direct fluoroscopic guidance. ${ }^{95}$ Prophylactic pinning of the contralateral hip should be considered in patients who are at a high risk for bilateral SCFE. ${ }^{96}$

\section{Genu Valgum/Varum}

Genu valgum is more common among children with obesity than healthy-weight peers (55\% vs $2 \%$, respectively), ${ }^{97}$ and adolescents with obesity tend to maintain abnormal genu valgus alignment of knees. Prolonged valgus is associated with lower activity levels; although whether this is secondary to pain, balance, endurance, or a combination is unknown. ${ }^{97,98}$ Genu valgum increases stress on the lateral knee, increasing risk for osteoarthritis. ${ }^{99}$ Adolescent females with obesity are at risk for a rapidly progressive form of genu valgum. ${ }^{100}$

A tibio-femoral angle ("Q angle") $>15$ degrees on examination is abnormal (Fig 3). The intermalleolar distance is unreliable because thigh mass influences the intermalleolar distance. A weight-bearing anterior-posterior radiograph provides an accurate measure

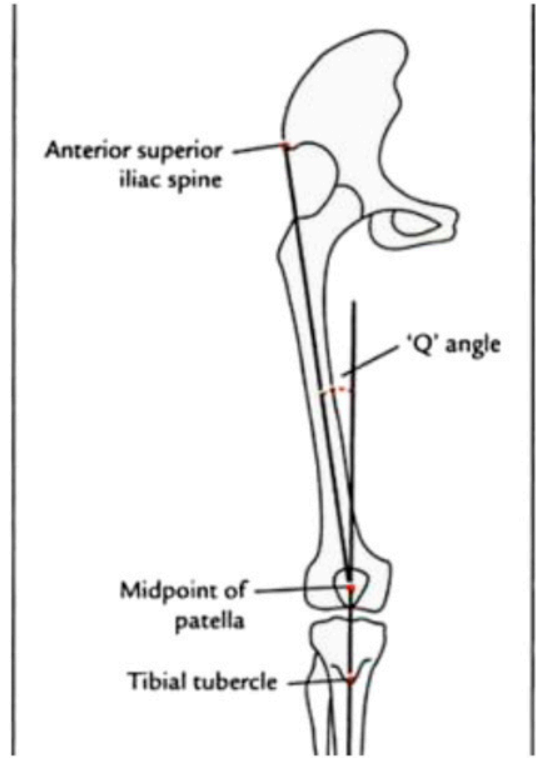

FIGURE 3

Measurement of tibio-femoral angle (Q-angle) Photograph from PhysioPedia (http://www. physio-pedia.com/\%27Q\%27_Angle). Accessed February 21, 2015.

of the tibio-femoral angle and screens for skeletal dysplasias (hypophosphatemic rickets, multiple epiphyseal dysplasia, pseudoachondroplasia). ${ }^{101}$ Patients with Q-angle greater than 15 degrees, hip drop, pain, or imbalance should be referred to orthopedics for evaluation. Surgical correction of valgus can prevent progression in severe cases.

\section{Pes Planus}

Pes planus, or "flatfoot," is common among children with obesity and may cause pain in the feet and lower legs, ${ }^{102}$ particularly after long walks or exercise. ${ }^{103,104}$ In cross-sectional studies ${ }^{105-116}$ prevalence ranges from $14 \%$ to $67 \%$ and increases with weight. Clinicians should distinguish between flexible and rigid pes planus. ${ }^{117}$ Rigid pes planus is present when standing (weightbearing) and sitting (non-weight bearing) and is commonly indicative of underlying pathology, Flexible pes planus is present with standing (weight bearing) only, and is more 


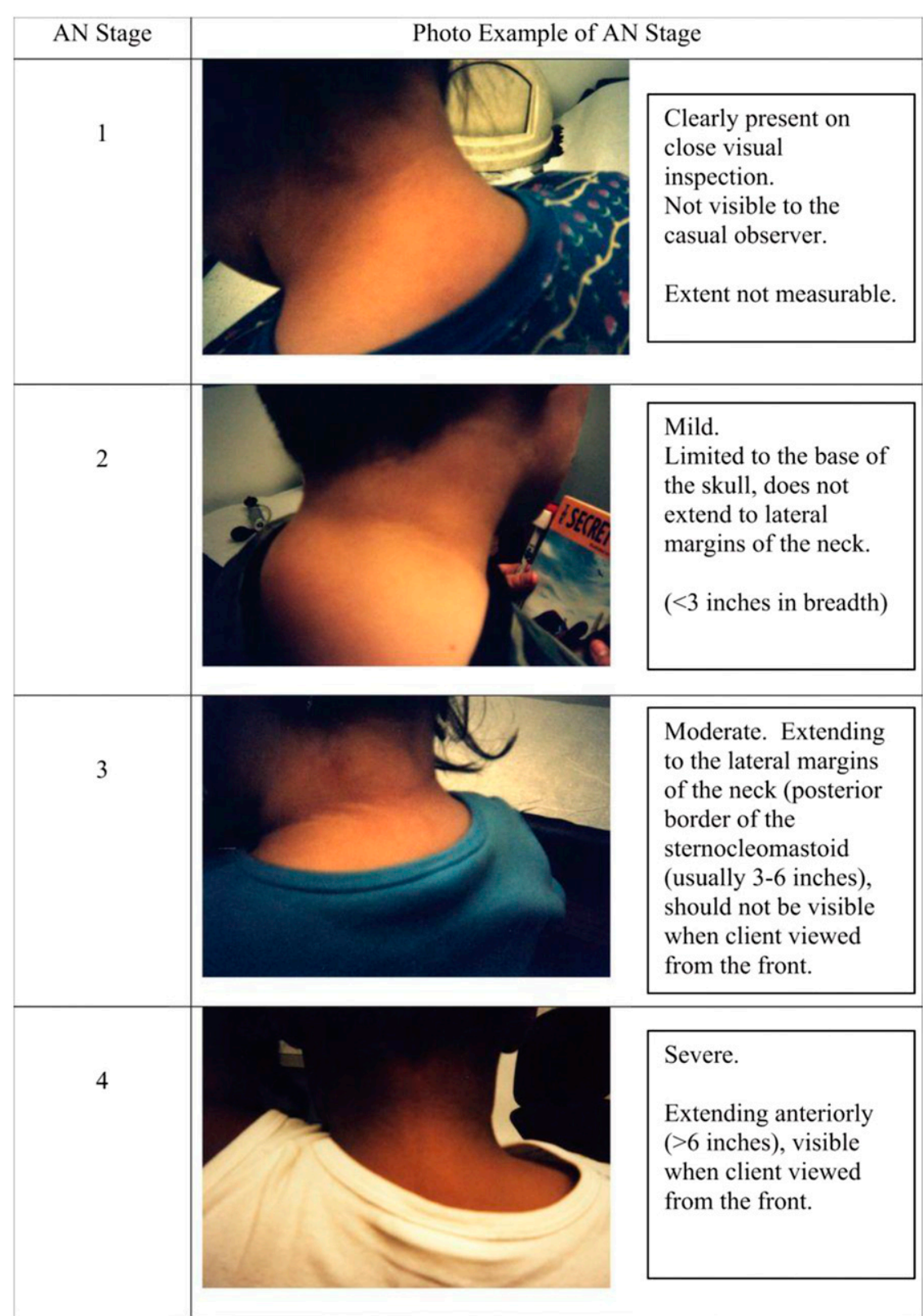

FIGURE 4

Burke Scale for AN quantification. ${ }^{20}$

common and usually asymptomatic. Clinicians should investigate age of onset, family history, associated medical conditions, associated symptoms, trauma history, activity level, and any previous treatment. ${ }^{117}$ Pain may be reported in the medial foot, leg, or knee. Treatment includes orthotics, nonsteroidal antiinflammatory medications, and stretching. ${ }^{118}$ Children with rigid pes planus or any pes planus that does not improve with conservative management should be referred to an orthopedist, podiatrist, or physical therapist.

\section{SKIN}

\section{Acanthosis Nigricans}

Acanthosis nigricans (AN) is thickened and dark skin, occasionally pruritic, at the nape of the neck (99\%), axillae (73\%), and less commonly, groin, eyelids, dorsal hands, and other areas exposed to friction. 17,18 "Acanthosis" refers to thickening of the superficial epithelium and not excess melanin as is commonly believed. ${ }^{18}$ The proposed biochemical mechanism involves local ${ }^{17}$ cutaneous and circulating ${ }^{119}$ growth factors.

The differential diagnosis includes medication side effects (glucocorticoids, niacin, insulin, oral contraceptives, or protease inhibitors ${ }^{18}$ ) and, uncommonly, visceral malignancy. ${ }^{19}$ However, among children with obesity, AN is strongly predictive of insulin resistance, ${ }^{120-122}$ particularly among Native American, African American, and Hispanic children, ${ }^{123}$ adolescents, and those with positive family history for type 2 diabetes mellitus. ${ }^{17,122,124-127}$ Clinicians can quantify the severity of AN using the Burke scale (Fig 4), which is a reliable and reproducible grading system but does not correlate directly with severity of insulin resistance or predict type 2 diabetes. ${ }^{128}$ The presence of warts or skin tags within AN represents more severe disease. ${ }^{129}$

The American Diabetes Association and the American Academy of Pediatrics recommend that children aged $\geq 10$ with BMI $\geq 85$ th percentile with $\geq 2$ risk factors (BMI $\geq 95$ th percentile, African American/Hispanic/Native American/Asian American/Pacific Islander, positive family history) should be screened every other year for diabetes using a fasting glucose or a 2-hour oral glucose tolerance test. ${ }^{130}$

Acanthosis improves with BMI reduction. Tretinoin $0.1 \%$ gel, either alone or in combination with $12 \%$ ammonium lactate cream, may reduce AN severity. Among adolescents, metformin $500 \mathrm{mg}$ 3 times daily may also lead to decreased severity rating. ${ }^{131}$ 


\section{Hirsutism and Acne}

Hirsutism and/or acne in an obese female adolescent may represent polycystic ovarian syndrome (PCOS). PCOS affects $4 \%$ to $12 \%$ of reproductive-age women and increases the risk of developing type 2 diabetes mellitus by three- to sevenfold. ${ }^{132}$ The revised clinical diagnosis of PCOS is based on the Rotterdam Consensus and requires 2 of the following: clinical evidence of hyperandrogenism (acne, hirsutism, male-pattern alopecia), ovulatory dysfunction (chronic anovulation/irregular menses), and polycystic ovaries. ${ }^{21}$ The odds of developing PCOS are 3 times higher for girls who are overweight, 6 times for girls who are obese, and 15 times for those who are severely obese. ${ }^{132}$ Adolescents are more likely than older women to present with hirsutism and more likely to have associated insulin resistance. ${ }^{133,134}$ The diagnosis is clinical and is supported by elevated free testosterone. The treatment of PCOS includes oral hormonal contraceptives and metformin, and referral to a pediatric endocrinologist where available is indicated. ${ }^{135}$ Hirsutism may also be treated with spironolactone at a starting dose of 25 mg twice daily; potassium levels and blood pressure should be measured at baseline and monitored regularly. Acne, as part of PCOS, is likely to respond to oral hormonal therapy alone or in combination with topical treatments.

\section{Striae}

Striae ("stretch marks") are linear, smooth bands of atrophic skin that initially appear erythematous, progressing to purple then white.

They appear in lines perpendicular to the direction of greatest tension, lack hair follicles, and are generally symmetrical and bilateral. ${ }^{22}$ Striae are on multiple sites in $40 \%$ of patients, ${ }^{136}$ most commonly on thighs (73\%), arms (42\%), and abdomen (30\%) and less frequently on back, buttocks, and knees. Although their exact pathogenesis is not completely understood, mechanical, hormonal, and genetic factors are implicated. ${ }^{23}$

Striae are present in $40 \%$ of children with obesity, ${ }^{23,136}$ increasing with age and longer duration of obesity. The differential includes pregnancy, Cushing syndrome, and topical corticosteroid use. Striae secondary to exogenous obesity are lighter, narrower, and less atrophic than in those with Cushing syndrome. ${ }^{23}$ Although Cushing syndrome is rare, clinicians should consider it among patients with short stature, obesity, striae, and HTN. ${ }^{137}$ Treatment options for striae include topical tretinoin and laser treatment, which may decrease erythema; however, most treatments are not effective. ${ }^{22}$

\section{Intertrigo}

Intertrigo refers to macerated, erythematous plaques that develop in genitocrural, abdominal, axillary, and inframamillary folds as the result of friction and moisture. ${ }^{23}$ Obesity alters skin physiology, increasing the rate of transepidermal water loss ${ }^{138}$ and raising the skin's $\mathrm{pH} .{ }^{139}$ These changes increase skin moisture and decrease resistance to colonization with Candida albicans. Symptoms of intertrigo include itching and burning. Physical findings may include scaling erythema with macules, papules, or pustules. Satellite lesions suggest candidiasis, and foul odor suggests bacterial superinfection. Clinicians should examine skin folds closely, particularly in adolescents with severe obesity. Intertrigo can be prevented by good skin hygiene and drying powders. Treatment includes topical antifungals or antibacterials.

\section{Pannus}

Pannus (or "panniculus"), refers to excess skin and subcutaneous fat below the umbilicus. ${ }^{24}$ The panniculus can become symptomatic when it folds over the waistline, or when it develops intertrigo. ${ }^{24}$ The panniculus is a high-risk area for severe intertrigo, candidal or bacterial infections, folliculitis, abscesses, and gangrene. ${ }^{140}$ Patients may not disclose pain or discomfort from panniculus because of embarrassment or shame. Clinicians can provide counseling regarding comfortable waistbands and hygienic (drying) measures.

\section{PSYCHIATRIC}

\section{Flat Affect}

Psychological complications are common among children with obesity who are seeking treatment. ${ }^{141,142}$ Nearly $40 \%$ of children with morbid obesity being evaluated for bariatric surgery report clinically significant symptoms of depression, ${ }^{143}$ as do $11 \%$ to $34 \%$ of youth seeking traditional weight management treatment. ${ }^{144}$ Adolescent girls with obesity are at increased risk for depression (55\% vs 42\%). ${ }^{145}$ Adolescents who experience weightrelated teasing are twice as likely to report depressive symptoms than those who were not teased. ${ }^{146}$ The association is bidirectional; adolescents with depression are also more likely to have obesity. ${ }^{147}$ Depression in childhood is associated with obesity in adulthood. ${ }^{148}$

Depression impairs patients' ability to implement behavior change and medical recommendations ${ }^{149}$ and is associated with higher rates of attrition from pediatric weight management programs. ${ }^{150}$ Recommended primary care screening methods ${ }^{151}$ include the 9-item Patient Health Questionnaire-9152 and the 2-item Patient Health Questionnaire-2 $2^{153}$ for adolescents and the internalizing subscale items of the Pediatric Symptom Checklist for younger children. ${ }^{154}$ Positive screens should 
trigger referral to a mental

health specialist for

management. ${ }^{151}$

\section{SUMMARY}

The clinician is a critical part of the treatment of obesity among children and adolescents. Providers are encouraged to screen for obesity using the BMI, discuss weight status with parents and children, and offer dietary and activity counseling. A comprehensive and targeted physical examination will aid the clinician in assessing severity and need for further evaluation or treatment of comorbid conditions. Physical examination findings will guide the clinician to detect and treat health conditions that may otherwise lead to future disability and inactivity, will provide a non-invasive mechanism to follow progression of weight-related co-comorbidities, and will help to engage families in understanding effects of excess weight on their child' health.

\section{ACKNOWLEDGMENTS}

Amanda Kimburg, MS3 and Adam Van Mason, MD contributed to the literature review and initial drafting of portions of the manuscript. Janna Howard, BS, contributed to reference organization and formatting.

\section{ABBREVIATIONS}

AN: acanthosis nigricans

BP: blood pressure

DBP: diastolic blood pressure

HR: heart rate

HTN: hypertension

IIH: idiopathic intracranial hypertension

LVH: left ventricular hypertrophy

NAFLD: nonalcoholic fatty liver disease

OSA: obstructive sleep apnea

PCOS: polycystic ovarian syndrome

SCFE: slipped capital femoral epiphysis

SBP: systolic blood pressure T2D: type 2 diabetes

Drs Hampl, Lazorik, Collier, and Wood conducted the literature search and literature review, drafted portions of the manuscript, and revised the manuscript; and all authors approved the final manuscript as submitted.

DOI: $10.1542 /$ peds.2015-1766

Accepted for publication Aug 5, 2015

Address correspondence to Sarah Armstrong, MD, 4020 North Roxboro St, Durham NC 27704. E-mail: sarah.c.armstrong@duke.edu

PEDIATRICS (ISSN Numbers: Print, 0031-4005; Online, 1098-4275).

Copyright (C) 2016 by the American Academy of Pediatrics

FINANCIAL DISCLOSURE: The authors have indicated they have no financial relationships relevant to this article to disclose.

FUNDING: No external funding.

POTENTIAL CONFLICT OF INTEREST: Dr Hampl is a consultant for SIMmersion. The other authors have indicated they have no potential conflicts of interest to disclose.

\section{REFERENCES}

1. National High Blood Pressure Education Program Working Group on High Blood Pressure in Children and Adolescents. The fourth report on the diagnosis, evaluation, and treatment of high blood pressure in children and adolescents. Pediatrics. 2004;114(suppl 2, 4th Report):555-576

2. Feld LG, Corey H. Hypertension in childhood. Pediatr Rev. 2007;28(8):283-298

3. Mazor S, Mazor R. Approach to the child with tachycardia. UpToDate. June 23, 2014. Available at: http:// www.uptodate.com/contents/ approach-to-the-child-withpalpitations. Accessed December 7, 2015
4. Chianese J. Short stature. Pediatr Rev. 2005;26(1):36-37

5. Distelmaier F, Sengler U, MessingJuenger M, Assmann B, Mayatepek E, Rosenbaum T. Pseudotumor cerebri as an important differential diagnosis of papilledema in children. Brain Dev. 2006;28(3):190-195

6. Georgiadis E, Papandreou L, Evangelopoulou C, et al. Incidence of gynaecomastia in 954 young males and its relationship to somatometric parameters. Ann Hum Biol. 1994;21(6):579-587

7. Einav-Bachar R, Phillip M, AurbachKlipper Y, Lazar L. Prepubertal gynaecomastia: aetiology, course and outcome. Clin Endocrinol (Oxf). 2004;61(1):55-60
8. Ersöz H, Onde ME, Terekeci H, Kurtoglu S, Tor H. Causes of gynaecomastia in young adult males and factors associated with idiopathic gynaecomastia. Int J Androl. 2002;25(5):312-316

9. Lo JC, Mulligan K, Tai VW, Algren H, Schambelan M. "Buffalo hump" in men with HIV-1 infection. Lancet. 1998;351(9106):867-870

10. Wolf DC. Evaluation of the size, shape, and consistency of the liver. In: Walker HK, Hall WD, Hurts JW, eds. Clinical Methods: The History, Physical, and Laboratory Examinations. 3rd ed. Boston, MA: Butterworths; 1990

11. Wolf AD, Lavine JE. Hepatomegaly in neonates and children. Pediatr Rev 2000;21(9):303-310 
12. Bergeson PS, Hopkin RJ, Bailey RB Jr, McGill LC, Piatt JP. The inconspicuous penis. Pediatrics. 1993;92 (6):794-799

13. Goldberg CJ, Moore DP, Fogarty EE, Dowling FE. Scoliosis: a review. Pediatr Surg Int. 2008;24(2):129-144

14. Houghton KM. Review for the generalist: evaluation of pediatric hip pain. Pediatr Rheumatol Online J. 2009;7:10

15. Stevens PM, Holmstrom MC. Pediatric genu varum. 2013. Available at: http:// emedicine.medscape.com/article/ 1355974-overview. Accessed April 19, 2015

16. Buchanan M, Berlet GC, Raissi A. Pes planus. 2014. Available at: http:// emedicine.medscape.com/article/ 1236652-overview. Accessed April 19, 2015

17. De Sanctis V, Soliman A, Marsciani $A$, et al. Acanthosis nigricans in adolescents: a practical approach. Georgian Med News. 2013;(222):73-78

18. Higgins SP, Freemark M, Prose NS. Acanthosis nigricans: a practical approach to evaluation and management. Dermatol Online J. 2008;14(9):2

19. Sinha S, Schwartz RA. Juvenile acanthosis nigricans. J Am Acad Dermatol. 2007;57(3):502-508

20. Burke JP, Hale DE, Hazuda HP, Stern MP. A quantitative scale of acanthosis nigricans. Diabetes Care. 1999;22(10):1655-1659

21. Legro RS, Arslanian SA, Ehrmann DA, et al; Endocrine Society. Diagnosis and treatment of polycystic ovary syndrome: an Endocrine Society clinical practice guideline. J Clin Endocrinol Metab. 2013;98(12):4565-4592

22. Scheinfeld NS. Obesity and dermatology. Clin Dermatol. 2004;22(4):303-309

23. Yosipovitch G, DeVore A, Dawn A. Obesity and the skin: skin physiology and skin manifestations of obesity. $J$ Am Acad Dermatol. 2007;56(6):901-916, quiz 917-920

24. Borud LJ, Warren AG. Body contouring in the postbariatric surgery patient. J Am Coll Surg. 2006;203(1):82-93
25. Babinska K, Kovacs L, Janko V, Dallos T, Feber J. Association between obesity and the severity of ambulatory hypertension in children and adolescents. J Am Soc Hypertens. 2012;6(5):356-363

26. Flynn J. The changing face of pediatric hypertension in the era of the childhood obesity epidemic. Pediatr Nephrol. 2013;28(7):1059-1066

27. Becton LJ, Shatat IF, Flynn JT. Hypertension and obesity: epidemiology, mechanisms and clinical approach. Indian J Pediatr. 2012;79(8):1056-1061

28. Csábi GY, Juricskay S, Molnár D. Urinary cortisol to cortisone metabolites in hypertensive obese children. J Endocrinol Invest. 2000;23(7):435-439

29. Baráth A, Túri S, Németh I, et al. Different pathomechanisms of essential and obesity-associated hypertension in adolescents. Pediatr Nephrol. 2006;21(10):1419-1425

30. Li S, Chen W, Yun M, et al. Sex and race (black-white) differences in the relationship of childhood risk factors to adulthood arterial stiffness: the Bogalusa Heart Study. Am J Med Sci. 2014;348(2):101-107

31. Ribstein J, du Cailar G, Mimran A. Combined renal effects of overweight and hypertension. Hypertension. 1995;26(4):610-615

32. Sasatomi Y, Tada M, Uesugi N, Hisano S, Takebayashi S. Obesity associated with hypertension or hyperlipidemia accelerates renal damage. Pathobiology. 2001;69(2):113-118

33. Expert Panel on Integrated Guidelines for Cardiovascular Health and Risk Reduction in Children and Adolescents; National Heart, Lung, and Blood Institute. Expert panel on integrated guidelines for cardiovascular health and risk reduction in children and adolescents: summary report. Pediatrics. 2011;128(suppl 5):S213-S256

34. Brady TM, Fivush B, Flynn JT, Parekh R. Ability of blood pressure to predict left ventricular hypertrophy in children with primary hypertension. J Pediatr. 2008;152(1):73-78.e71
35. Movahed MR, Bates S, Strootman D, Sattur S. Obesity in adolescence is associated with left ventricular hypertrophy and hypertension. Echocardiography. 2011;28(2): 150-153

36. Gillette PC, Garson A Jr, Porter CJ, McNamara DG. Dysrhythmias. In: Adams FH, Emmanouilides GC, Riemenschneider TA, eds. Moss' Heart Disease in Infants, Children and Adolescents. 4th ed. Baltimore, MD: Williams \& Wilkin; 1989

37. Baba R, Koketsu M, Nagashima M, Inasaka H, Yoshinaga M, Yokota M. Adolescent obesity adversely affects blood pressure and resting heart rate. Circ J. 2007;71(5):722-726

38. Sorof JM, Poffenbarger T, Franco K, Bernard L, Portman RJ. Isolated systolic hypertension, obesity, and hyperkinetic hemodynamic states in children. J Pediatr. 2002;140(6):660-666

39. Julius S, Valentini M, Palatini P. Overweight and hypertension: a 2-way street? Hypertension. 2000;35(3):807-813

40. Palatini P, Julius S. Elevated heart rate: a major risk factor for cardiovascular disease. Clin Exp Hypertens. 2004;26(7-8):637-644

41. He Q, Karlberg J. BMl in childhood and its association with height gain, timing of puberty, and final height. Pediatr Res. 2001;49(2):244-251

42. Mercille G, Ospina LH. Pediatric idiopathic intracranial hypertension: a review. Pediatr Rev. 2007;28(11):e77-e86

43. Faz G, Butler IJ, Koenig MK. Incidence of papilledema and obesity in children diagnosed with idiopathic "benign" intracranial hypertension: case series and review. J Child Neurol. 2010;25(11):1389-1392

44. Weig SG. Asymptomatic idiopathic intracranial hypertension in young children. J Child Neurol. 2002;17 (3):239-241

45. Ball AK, Clarke CE. Idiopathic intracranial hypertension. Lancet Neurol. 2006;5(5):433-442

46. Frisén L. Swelling of the optic nerve head: a staging scheme. 
$\checkmark$ Neurol Neurosurg Psychiatry. 1982;45(1):13-18

47. Hooley M, Skouteris H, Boganin C, Satur J, Kilpatrick N. Body mass index and dental caries in children and adolescents: a systematic review of literature published 2004 to 2011. Syst Rev. 2012;1(1):57

48. Hayden C, Bowler J0, Chambers S, et al. Obesity and dental caries in children: a systematic review and meta-analysis. Community Dent Oral Epidemiol. 2013;41(4):289-308

49. Modéer T, Blomberg CC, Wondimu B, Julinn A, Marcus C. Association between obesity, flow rate of whole saliva, and dental caries in adolescents. Obesity (Silver Spring). 2010;18(12):2367-2373

50. Pannunzio E, Amancio OMS, Vitalle MS, Souza DN, Mendes FM, Nicolau J. Analysis of the stimulated whole saliva in overweight and obese school children. Rev Assoc Med Bras. 2010;56(1):32-36

51. González LC, Villa CG, Cárdenas AC. Prader Willi syndrome: saliva quantification and culture in 10 patients. Med Oral Patol Oral Cir Bucal. 2008;13(12):E774-777

52. Saeves R, Nordgarden H, Storhaug K, Sandvik L, Espelid I. Salivary flow rate and oral findings in Prader-Willi syndrome: a case-control study. Int J Paediatr Dent. 2012;22(1):27-36

53. Must A, Phillips SM, Tybor DJ, Lividini K, Hayes C. The association between childhood obesity and tooth eruption. Obesity (Silver Spring). 2012;20(10):2070-2074

54. Sánchez-Pérez L, Irigoyen ME, Zepeda $M$. Dental caries, tooth eruption timing and obesity: a longitudinal study in a group of Mexican schoolchildren. Acta Odontol Scand. 2010;68(1):57-64

55. Preis SR, Massaro JM, Hoffmann $U$, et al. Neck circumference as a novel measure of cardiometabolic risk: the Framingham Heart study. J Clin Endocrinol Metab. 2010;95(8):3701-3710

56. Laakso M, Matilainen V, KeinanenKiukaanniemi S. Association of neck circumference with insulin resistancerelated factors. Int J Obes Relat Metab Disord. 2002;26(6):873-875
57. Jordan AS, McSharry DG, Malhotra A. Adult obstructive sleep apnoea. Lancet. 2014;383(9918):736-747

58. Androutsos 0, Grammatikaki E, Moschonis G, et al. Neck circumference: a useful screening tool of cardiovascular risk in children. Pediatr Obes. 2012;7(3):187-195

59. de Sousa Caixeta JA, Saramago AM, de Cacia Pradella-Hallinan ML, Moreira GA, Tufik S, Fujita RR. Waistto-height ratio distinguish obstructive sleep apnea from primary snoring in obese children. Sleep Breath. 2015;19(1):231-237

60. Lam YY, Chan EY, Ng DK, et al. The correlation among obesity, apneahypopnea index, and tonsil size in children. Chest. 2006;130(6):1751-1756

61. Dayyat E, Kheirandish-Gozal L, Sans Capdevila 0, Maarafeya MM, Gozal D. Obstructive sleep apnea in children: relative contributions of body mass index and adenotonsillar hypertrophy. Chest. 2009;136(1):137-144

62. Kang KT, Chou CH, Weng WC, Lee $\mathrm{PL}$, Hsu WC. Associations between adenotonsillar hypertrophy, age, and obesity in children with obstructive sleep apnea. PLoS One. 2013;8(10):e78666

63. Hsing AW, McLaughlin JK, Cocco P, Co Chien HT, Fraumeni JF Jr. Risk factors for male breast cancer (United States). Cancer Causes Control. 1998;9(3):269-275

64. Hammond DC. Surgical correction of gynecomastia. Plast Reconstr Surg. 2009;124(1 Suppl):61e-68e

65. Rosen H, Webb ML, DiVasta AD, et al. Adolescent gynecomastia: not only an obesity issue. Ann Plast Surg. 2010;64(5):688-690

66. Joseph PR, Fort P. Observations on the buffalo hump. Clin Pediatr (Phila). 1999;38(10):622-623

67. Schwimmer JB, Deutsch R, Kahen T, Lavine JE, Stanley C, Behling C. Prevalence of fatty liver in children and adolescents. Pediatrics. 2006;118(4):1388-1393

68. Schwimmer JB, McGreal N, Deutsch $\mathrm{R}$, Finegold MJ, Lavine JE. Influence of gender, race, and ethnicity on suspected fatty liver in obese adolescents. Pediatrics. 2005;115(5).
Available at: www.pediatrics.org/cgi/ content/full/115/5/e561

69. Feldstein AE, Charatcharoenwitthaya P, Treeprasertsuk S, Benson JT, Enders FB, Angulo P. The natural history of non-alcoholic fatty liver disease in children: a follow-up study for up to 20 years. Gut. 2009;58(11):1538-1544

70. Baker S, Barlow S, Cochran W, et al. Overweight children and adolescents: a clinical report of the North American Society for Pediatric Gastroenterology, Hepatology and Nutrition. J Pediatr Gastroenterol Nutr. 2005;40(5):533-543

71. Fishbein M, Mogren J, Mogren C, Cox S, Jennings R. Undetected hepatomegaly in obese children by primary care physicians: a pitfall in the diagnosis of pediatric nonalcoholic fatty liver disease. Clin Pediatr (Phila). 2005;44(2):135-141

72. Fishbein MH, Miner M, Mogren C, Chalekson J. The spectrum of fatty liver in obese children and the relationship of serum aminotransferases to severity of steatosis. J Pediatr Gastroenterol Nutr. 2003;36(1):54-61

73. Gupta K, Dhawan A, Abel C, Talley N, Attia J. A re-evaluation of the scratch test for locating the liver edge. BMC Gastroenterol. 2013;13:35

74. Akcam M, Boyaci A, Pirgon 0, Koroglu M, Dundar BN. Importance of the liver ultrasound scores in pubertal obese children with nonalcoholic fatty liver disease. Clin Imaging. 2013;37(3):504-508

75. Warren AG, Peled ZM, Borud LJ. Surgical correction of a buried penis focusing on the mons as an anatomic unit. J Plast Reconstr Aesthet Surg. 2009;62 (3):388-392

76. King ICC, Tahir A, Ramanathan C, Siddiqui H. Buried penis: evaluation of outcomes in children and adults, modification of a unified treatment algorithm, and review of the literature. ISRN Urol. 2013;2013:109349

77. Crawford BS. Buried penis. Br J Plast Surg. 1977;30(1):96-99

78. Blakemore VJ, Fink PW, Lark SD, Shultz SP. Mass affects lower extremity muscle activity patterns in children's gait. Gait Posture. 2013;38(4):609-613

79. de Sá Pinto AL, de Barros Holanda PM, Radu AS, Villares SM, Lima FR. 
Musculoskeletal findings in obese children. J Paediatr Child Health. 2006;42(6):341-344

80. Shultz SP, D'Hondt E, Fink PW, Lenoir M, Hills AP. The effects of pediatric obesity on dynamic joint malalignment during gait. Clin Biomech (Bristol, Avon). 2014;29(7):835-838

81. Matusik E, Durmała J, Matusik P, Piotrowski J. Evaluation of nutritional status of children and adolescents with idiopathic scoliosis: a pilot study. Ortop Traumatol Rehabil. 2012;14(4):351-362

82. El-Hawary R, Chukwunyerenwa C. Update on evaluation and treatment of scoliosis. Pediatr Clin North Am. 2014;61(6):1223-1241

83. O'Neill PJ, Karol LA, Shindle MK, et al. Decreased orthotic effectiveness in overweight patients with adolescent idiopathic scoliosis. J Bone Joint Surg Am. 2005;87(5):1069-1074

84. Hardesty CK, Poe-Kochert C, Son-Hing JP, Thompson GH. Obesity negatively affects spinal surgery in idiopathic scoliosis. Clin Orthop Relat Res. 2013;471(4):1230-1235

85. Kenanidis E, Potoupnis ME, Papavasiliou KA, Sayegh FE, Kapetanos GA. Adolescent idiopathic scoliosis and exercising: is there truly a liaison? Spine. 2008;33(20):2160-2165

86. Smith AJ, O'Sullivan PB, Beales DJ, de Klerk N, Straker LM. Trajectories of childhood body mass index are associated with adolescent sagittal standing posture. Int J Pediatr Obes. 2011;6(2-2):e97-e106

87. Gettys FK, Jackson JB, Frick SL. Obesity in pediatric orthopaedics. Orthop Clin North Am. 2011;42(1):95-105, vii

88. Peck D. Slipped capital femoral epiphysis: diagnosis and management. Am Fam Physician. 2010;82(3):258-262

89. Manoff EM, Banffy MB, Winell JJ. Relationship between body mass index and slipped capital femoral epiphysis. J Pediatr Orthop. 2005;25(6):744-746

90. Wilcox PG, Weiner DS, Leighley B. Maturation factors in slipped capital femoral epiphysis. J Pediatr Orthop. 1988;8(2):196-200

91. Loder RT. The demographics of slipped capital femoral epiphysis. An international multicenter study. Clin Orthop Relat Res. 1996; (322):8-27

92. Bhatia NN, Pirpiris M, Otsuka NY. Body mass index in patients with slipped capital femoral epiphysis. J Pediatr Orthop. 2006;26(2):197-199

93. Spero CR, Masciale JP, Tornetta P III, Star MJ, Tucci JJ. Slipped capital femoral epiphysis in black children: incidence of chondrolysis. J Pediatr Orthop. 1992;12(4):444-448

94. Perron AD, Miller MD, Brady WJ. Orthopedic pitfalls in the ED: slipped capital femoral epiphysis. Am J Emerg Med. 2002;20(5):484-487

95. Westberry DE, Davids JR, Cross A, Tanner SL, Blackhurst DW. Simultaneous biplanar fluoroscopy for the surgical treatment of slipped capital femoral epiphysis. J Pediatr Orthop. 2008;28(1):43-48

96. Azzopardi T, Sharma S, Bennet GC. Slipped capital femoral epiphysis in children aged less than 10 years. J Pediatr Orthop B. 2010;19(1):13-18

97. McMillan AG, Pulver AM, Collier DN, Williams DS. Sagittal and frontal plane joint mechanics throughout the stance phase of walking in adolescents who are obese. Gait Posture 2010;32(2):263-268

98. Kaspiris A, Zaphiropoulou C, Vasiliadis E. Range of variation of genu valgum and association with anthropometric characteristics and physical activity: comparison between children aged 3-9 years. J Pediatr Orthop $B$. 2013;22(4):296-305

99. Sharma L, Song J, Felson DT, Cahue $S$, Shamiyeh E, Dunlop DD. The role of knee alignment in disease progression and functional decline in knee osteoarthritis. JAMA. 2001;286(2):188-195

100. Zhang AL, Exner GU, Wenger DR. Progressive genu valgum resulting from idiopathic lateral distal femoral physeal growth suppression in adolescents. J Pediatr Orthop. 2008;28(7):752-756

101. Greene WB; American Academy of Orthopedic Surgeons Staff; American Academy of Pediatrics Staff. Essentials of musculoskeletal care. 2nd ed.
Rosemont, IL: American Academy of Orthopaedic; 2001

102. Wearing SC, Smeathers JE, Sullivan PM, Yates B, Urry SR, Dubois P. Plantar fasciitis: are pain and fascial thickness associated with arch shape and loading? Phys Ther. 2007;87 (8):1002-1008

103. Hills AP, Hennig EM, McDonald M, Bar-Or 0. Plantar pressure differences between obese and non-obese adults: a biomechanical analysis. Int J Obes Relat Metab Disord. 2001;25(11):1674-1679

104. Willems TM, De Clercq D, Delbaere K, Vanderstraeten G, De Cock A, Witvrouw E. A prospective study of gait related risk factors for exercise-related lower leg pain. Gait Posture. 2006;23(1):91-98

105. Adoracion Villarroya M, Manuel Esquivel J, Tomas C, Buenafe A, Moreno L. Foot structure in overweight and obese children. Int J Pediatr Obes. 2008;3(1):39-45

106. Chang JH, Wang SH, Kuo CL, Shen HC, Hong YW, Lin LC. Prevalence of flexible flatfoot in Taiwanese schoolaged children in relation to obesity, gender, and age. Eur J Pediatr. 2010;169(4):447-452

107. Chen KC, Yeh CJ, Tung LC, Yang JF, Yang SF, Wang $\mathrm{CH}$. Relevant factors influencing flatfoot in preschoolaged children. Eur J Pediatr. 2011;170(7):931-936

108. Mauch M, Grau S, Krauss I, Maiwald C, Horstmann T. Foot morphology of normal, underweight and overweight children. Int J Obes. 2008;32(7):1068-1075

109. Mickle KJ, Steele JR, Munro BJ. Does excess mass affect plantar pressure in young children? Int J Pediatr 0bes. 2006;1(3):183-188

110. Mickle KJ, Steele JR, Munro BJ. The feet of overweight and obese young children: are they flat or fat? Obesity (Silver Spring). 2006;14(11):1949-1953

111. Pfeiffer M, Kotz R, Ledl T, Hauser G, Sluga M. Prevalence of flat foot in preschool-aged children. Pediatrics 2006;118(2):634-639

112. Riddiford-Harland DL, Steele JR, Baur LA. Medial midfoot fat pad thickness and plantar pressures: are these 
related in children? Int J Pediatr Obes. 2011;6(3-4):261-266

113. Riddiford-Harland DL, Steele JR, Baur LA. Are the feet of obese children fat or flat? Revisiting the debate. Int J Obes. 2011;35(1):115-120

114. Riddiford-Harland DL, Steele JR, Storlien LH. Does obesity influence foot structure in prepubescent children? Int J Obes Relat Metab Disord. 2000;24(5):541-544

115. Tenenbaum S, Hershkovich 0 , Gordon B, et al. Flexible pes planus in adolescents: body mass index, body height, and gender-an epidemiological study. Foot Ankle Int. 2013;34(6):811-817

116. Villarroya MA, Esquivel JM, Tomás C, Moreno LA, Buenafé A, Bueno G. Assessment of the medial longitudinal arch in children and adolescents with obesity: footprints and radiographic study. Eur J Pediatr. 2009;168(5):559-567

117. Harris EJ, Vanore JV, Thomas JL, Kravitz SR, Mendelson SA, Mendicino RW, et al Diagnosis and treatment of pediatric flatfoot. J Foot Ankle Surg. 2004;43(6):341-373

118. Rome K, Ashford RL, Evans A. Nonsurgical interventions for paediatric pes planus. Cochrane Database Syst Rev. 2010;(7):CD006311

119. Galhardo J, Hunt LP, Shield JP. Serum levels of pigment epitheliumderived factor (PEDF) are positively associated with acanthosis nigricans in obese adolescents. Diabet Med. 2012;29(7):e117-120

120. Abraham C, Rozmus CL. Is acanthosis nigricans a reliable indicator for risk of type 2 diabetes in obese children and adolescents? A systematic review. J School Nurs. 2012;28(3):195-205

121. Brickman WJ, Huang J, Silverman $\mathrm{BL}$, Metzger BE. Acanthosis nigricans identifies youth at high risk for metabolic abnormalities. J Pediatr. 2010;156(1):87-92

122. Fowler SP, Puppala S, Arya R, et al. Genetic epidemiology of cardiometabolic risk factors and their clustering patterns in Mexican American children and adolescents: the SAFARI Study. Hum Genet.

2013;132(9):1059-1071

123. Kluczynik CE, Mariz LS, Souza LC, Solano GB, Albuquerque FC, Medeiros CC. Acanthosis nigricans and insulin resistance in overweight children and adolescents. An Bras Dermatol. 2012;87 (4):531-537

124. Guran T, Turan S, Akcay T, Bereket A. Significance of acanthosis nigricans in childhood obesity. J Paediatr Child Health. 2008;44(6):338-341

125. Reeds DN, Stuart CA, Perez 0, Klein S. Adipose tissue, hepatic, and skeletal muscle insulin sensitivity in extremely obese subjects with acanthosis nigricans. Metabolism. 2006;55(12):1658-1663

126. Copeland K, Pankratz K, Cathey V, et al. Acanthosis Nigricans, insulin resistance (HOMA) and dyslipidemia among Native American children. J Okla State Med Assoc. 2006;99(1):19-24

127. Rafalson L, Pham TH, Willi SM, Marcus M, Jessup A, Baranowski T. The association between acanthosis nigricans and dysglycemia in an ethnically diverse group of eighth grade students. Obesity (Silver Spring). 2013;21(3):E328-E333

128. Scott LK, Hall LM. Reliability and validity of the acanthosis nigricans screening tool for use in elementary school-age children by school nurses. J School Nurs. 2012;28(6):442-447

129. Ahmed A, Matthews M, Browning JC. Verruca vulgaris in a plaque of acanthosis nigricans. Dermatol Online J. $2011 ; 17(6): 9$

130. Felszeghy E, Káposzta R, Juhász E, Kardos L, llyés I. Alterations of carbohydrate and lipoprotein metabolism in childhood obesityimpact of insulin resistance and acanthosis nigricans. $J$ Pediatr Endocrinol Metab. 2009;22(12):1117-1126

131. Romo A, Benavides S. Treatment options in insulin resistance obesityrelated acanthosis nigricans. Ann Pharmacother. 2008;42 (7):1090-1094

132. Christensen SB, Black MH, Smith N, et al. Prevalence of polycystic ovary syndrome in adolescents. Fertil Steril. 2013;100(2):470-477
133. Knudsen KL, Blank SK, Burt Solorzano

$\mathrm{C}$, et al. Hyperandrogenemia

in obese peripubertal girls: correlates and potential etiological determinants. Obesity (Silver Spring). 2010;18(11):2118-2124

134. Amato MC, Galluzzo A, Merlino S, Mattina A, Richiusa P, Criscimanna $A$, et al Lower insulin sensitivity differentiates hirsute from nonhirsute Sicilian women with polycystic ovary syndrome. Eur J Endocrinol. 2006;155(6):859-865

135. Epstein LH, Fletcher KD, O’Neill J, Roemmich JN, Raynor H, Bouton ME. Food characteristics, Iong-term habituation and energy intake. Laboratory and field studies. Appetite. 2013;60(1):40-50

136. Hsu HS, Chen W, Chen SC, Ko FD. Colored striae in obese children and adolescents. Zhonghua Minguo Xiao Er Ke Yi Xue Hui Za Zhi. 1996;37(5):349-352

137. Bruno 0D, Juárez-Allen L, Rossi MA, Longobardi V. In what clinical settings should Cushing's syndrome be suspected? Medicina (B Aires). 2009;69(6):674-680

138. Nino M, Franzese A, Ruggiero Perrino $\mathrm{N}$, Balato N. The effect of obesity on skin disease and epidermal permeability barrier status in children. Pediatr Dermatol. 2012;29(5):567-570

139. Yosipovitch G, Tur E, Cohen 0, Rusecki Y. Skin surface $\mathrm{pH}$ in intertriginous areas in NIDDM patients. Possible correlation to candidal intertrigo. Diabetes Care. 1993;16(4):560-563

140. Gallagher S, Gates JL. Obesity, panniculitis, panniculectomy, and wound care: understanding the challenges. J Wound 0stomy Continence Nurs. 2003;30(6):334-341

141. Vander Wal JS, Mitchell ER. Psychological complications of pediatric obesity. Pediatr Clin North Am. 2011;58(6):1393-1401, $\mathrm{x}$

142. Krebs NF, Himes JH, Jacobson D, Nicklas TA, Guilday P, Styne D. Assessment of child and adolescent overweight and obesity. Pediatrics. 2007;120(suppl 4):S193-S228

143. Zeller MH, Modi AC, Noll JG, Long JD, Inge TH. Psychosocial functioning 
improves following adolescent bariatric surgery. Obesity (Silver Spring). 2009;17 (5):985-990

144. Zeller MH, Modi AC. Predictors of health-related quality of life in obese youth. Obesity (Silver Spring). 2006;14(1):122-130

145. Anderson SE, Cohen P, Naumova EN, Jacques PF, Must A. Adolescent obesity and risk for subsequent major depressive disorder and anxiety disorder: prospective evidence. Psychosom Med. 2007;69(8):740-747

146. Eisenberg ME, Neumark-Sztainer D, Story M. Associations of weight-based teasing and emotional well-being among adolescents. Arch Pediatr Adolesc Med. 2003;157(8):733-738

147. Goodman E, Whitaker RC. A prospective study of the role of depression in the development and persistence of adolescent obesity. Pediatrics. 2002;110(3):497-504
148. Liem ET, Sauer PJ, Oldehinkel AJ, Stolk RP. Association between depressive symptoms in childhood and adolescence and overweight in later life: review of the recent literature. Arch Pediatr Adolesc Med. 2008;162(10):981-988

149. Dreyer ML, Egan AM. Psychosocial functioning and its impact on implementing behavioral interventions for childhood obesity. Prog Pediatr Cardiol. 2008;25(2):159-166

150. Zeller M, Kirk S, Claytor R, et al. Predictors of attrition from a pediatric weight management program. J Pediatr. 2004;144(4):466-470

151. Weitzman C, Wegner L; Section on Developmental and Behavioral Pediatrics; Committee on Psychosocial Aspects of Child and Family Health; Council on Early Childhood; Society for Developmental and Behavioral Pediatrics;

American Academy of Pediatrics. Promoting optimal development: screening for behavioral and emotional problems. Pediatrics. 2015;135(2):384-395

152. Kroenke K, Spitzer RL, Williams JB. The PHQ-9: validity of a brief depression severity measure. J Gen Intern Med. 2001;16(9):606-613

153. Kroenke K, Spitzer RL, Williams JB. The Patient Health Questionnaire-2: validity of a twoitem depression screener. Med Care. 2003;41(11):1284-1292

154. Gardner W, Murphy M, Childs G, et al. The PSC-17: a brief pediatric symptom checklist with psychosocial problem subscales. A report from PROS and ASPN. Ambul Child Health. 1999;5(3):225 


\section{Physical Examination Findings Among Children and Adolescents With Obesity: An Evidence-Based Review}

Sarah Armstrong, Suzanne Lazorick, Sarah Hampl, Joseph A. Skelton, Charles Wood, David Collier and Eliana M. Perrin

$$
\text { Pediatrics 2016;137; }
$$

DOI: 10.1542/peds.2015-1766 originally published online January 27, 2016;

$\begin{array}{ll}\begin{array}{l}\text { Updated Information \& } \\ \text { Services }\end{array} & \begin{array}{l}\text { including high resolution figures, can be found at: } \\ \text { http://pediatrics.aappublications.org/content/137/2/e20151766 } \\ \text { References }\end{array} \\ \text { This article cites } 126 \text { articles, } 18 \text { of which you can access for free at: } \\ \text { http://pediatrics.aappublications.org/content/137/2/e20151766\#BIBL } \\ \text { Subspecialty Collections } \\ \begin{array}{l}\text { This article, along with others on similar topics, appears in the } \\ \text { following collection(s): } \\ \text { Obesity } \\ \text { http://www.aappublications.org/cgi/collection/obesity_new_sub }\end{array} \\ \text { Permissions \& Licensing } & \begin{array}{l}\text { Information about reproducing this article in parts (figures, tables) or } \\ \text { in its entirety can be found online at: } \\ \text { http://www.aappublications.org/site/misc/Permissions.xhtml }\end{array} \\ \text { Information about ordering reprints can be found online: } \\ \text { Reprints } & \text { http://www.aappublications.org/site/misc/reprints.xhtml }\end{array}$




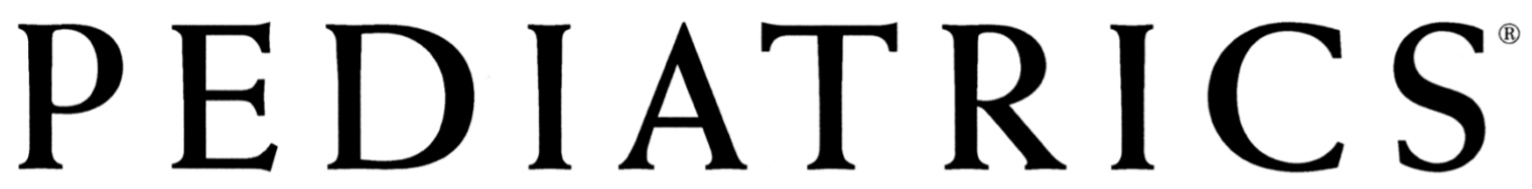

OFFICIAL JOURNAL OF THE AMERICAN ACADEMY OF PEDIATRICS

\section{Physical Examination Findings Among Children and Adolescents With Obesity:} An Evidence-Based Review

Sarah Armstrong, Suzanne Lazorick, Sarah Hampl, Joseph A. Skelton, Charles Wood, David Collier and Eliana M. Perrin

Pediatrics 2016;137;

DOI: 10.1542/peds.2015-1766 originally published online January 27, 2016;

The online version of this article, along with updated information and services, is located on the World Wide Web at: http://pediatrics.aappublications.org/content/137/2/e20151766

Pediatrics is the official journal of the American Academy of Pediatrics. A monthly publication, it has been published continuously since 1948. Pediatrics is owned, published, and trademarked by the American Academy of Pediatrics, 141 Northwest Point Boulevard, Elk Grove Village, Illinois, 60007. Copyright $\odot 2016$ by the American Academy of Pediatrics. All rights reserved. Print ISSN: 1073-0397. 